\title{
Measures for Building Lighting Performance in Malaysian Historical Buildings: A Systematic Review
}

\author{
Syahrul Nizam Kamaruzzaman ${ }^{1}$ and Nursyahida Zulkifli ${ }^{2}$ \\ ${ }^{1}$ Department of Building Surveying, Faculty of Built Environment, University of Malaya, Kuala Lumpur, \\ Malaysia \\ ${ }^{2}$ Research Centre, Building Performance and Diagnostic, Centre for Construction Building and Urban Studies \\ (CEBUS), Faculty of Built Environment, University of Malaya, Kuala Lumpur, Malaysia. \\ ${ }^{1}$ syahrulnizam2013@yahoo.com \& ${ }^{2}$ syahidazulkifli@gmail.com
}

\begin{abstract}
Developing countries, including Malaysia, focus on sustainable development. Development in our country should consider all the elements of sustainability in order to support the government effort as stated in the Ninth Malaysian Plan. Over the past five years, there has been a move away from constructing new buildings to refurbishing older ones. This is the meta-data analysis to review and evaluates the approach to the refurbishment of lighting and analyzes the existing energy efficiency policy and measures, for future improvement in energy efficiency in this type of building. This paper aims to assess the characteristics of electricity use and to identify specific information for potential energy conservation in lighting. The main sources of this literature review are journal articles, and internet searches. The study found that lighting building performance is measured by daylighting, lighting simulation and automatic lighting systems. Occupant satisfaction is another measure to determine the lighting performance in the building. This study adds to knowledge from the perspective of lighting performance. It offers new and valuable insights to enable Malaysia to achieve optimum energy efficiency, with financial savings as well as reducing the environmental impact.
\end{abstract}

Keywords: building regulations, energy efficiency, meta-data analysis, lighting performance, Uniform Building by-Law (UBBL)

\section{INTRODUCTION}

Patterns of energy consumption vary between different industries, buildings and sites, affected by the duration and nature of the period of occupation. Usually, a building that experiences high usage has high energy consumption. Energy efficiency measures should be carried out in order to improve overall building performance (Bassi, Yudken, \& Ruth, 2009). Energy saving can increase competitiveness for industry, through the cost reduction, economic growth and environmental issues (Bassi, Yudken, \& Ruth, 2009; Ozolina \& Roša, 2012).

Electricity is used for running the air-conditioning plant, lighting and other equipment in the building. Lighting consumption depends on the purpose of the building, use of daylight, illumination levels for certain areas and the hours of usage (Musa, Abdullah, Che-Ani, Tawil, \& Tahir, 2012). This means that the energy consumed in the buildings is mainly related to cooling and lighting, and high costs are incurred if the energy is not managed well. Electricity has many functions and, in addition to high-grade energy, it is required in the transportation of low-grade energy, for instance, in air-conditioning through a ducting system using a fan. The grade of energy used in a building is determined by the ability to perform work. 
The energy consumption increases with population growth, increasing demand for building services and comfort levels, and time spent inside buildings (Ozolina \& Roša, 2012). Lighting has the potential to improve energy saving in buildings (Boyano, Hernandez, \& Wolf, 2013). In fact, the energy use in buildings is reflected by the energy consumption in residential and commercial sectors (Ozolina \& Roša, 2012), and energy efficiency in buildings has become a primary objective for energy policy at regional, national and international levels. This paper presents an evaluation of lighting performance which can be applied to older Malaysian buildings through energy-efficiency refurbishment.

\section{HISTORIC BUILDINGS IN MALAYSIA}

Historic buildings are important assets of a nation's cultural resources, and Salleh and Ahmad (2009) categorized Malaysian buildings with an age of 50 years or more as historic or heritage buildings. In hot and humid countries like Malaysia, the year-round regime of heavy rains and high temperatures contributes to inconsistent fluctuations in indoor climate and does eventually create changes to the systems used in historic buildings.

Heritage buildings represent the most evident aspect of past history and culture, and Malaysia has a prosperous legacy of heritage buildings with high-quality of craftsmanship architecture. Kamal, Wahab and Ahmad (2008) described the heritage buildings built between 1800 and 1948 as 'pre-war buildings'. There are 20,787 heritage buildings throughout Malaysia (Kamal, Wahab \& Ahmad, 2008). The highest numbers are in Penang, followed by Perak, Johor, Malacca, Kuala Lumpur and other states.

Heritage buildings have unique characteristics. The older buildings were influenced by British architecture, divided into several styles such as Moorish, Tudor, Neo-Classical and Neo-Gothic (Kamaruzzaman \& Edwards, 2006). These buildings are notable historic features, examples of former craftsmanship. Their conservation and preservation is important since they are endowed with a sense of identity and continuity for future generations in this fast-changing world (Mustapa, Kamal, \& Zainul, 2005). Unfortunately, Yaacob (2010) found that many buildings in Malaysia are under-used or wrongly used by the occupants, resulting in dilapidation. The lack of maintenance and attention from the responsible parties, together with social problems, can lead to vandalism and abuse that increases the rate of wear and tear on buildings.

Most Malaysian heritage buildings were demolished in the 1970s because of urban development, and deterioration due to age, neglect, and higher maintenance costs (Kamal et al., 2008). In fact, heritage building conservation in Malaysia is still in its infancy (Kamal et al., 2008; Yaacob, 2010). Various authors have defined heritage building conservation in many ways, according to the scope and focus of their study. Conservation refers to the activities to maintain the character of the heritage buildings, including the work of preservation, restoration, reconstruction and adaptation. According to Harun (2011), conservation is defined as technical activities performed on historic buildings that involve physical activities in order to preseve the fabric and material of these buildings; conservation is a process to prevent decay, thus prolonging the life of the building. This argument is in line with Bernard (2003), who stated that conservation is the action taken by the responsible parties to prevent decay; it embraces all related actions to prolong the life of the cultural and national heritage for benefit of future generations. Despite the clear definition of conservation, people tend to understand it as a building renovation process in real life. This 
wrong perception and misunderstanding of conservation leads to a lack of change in the public attitude towards local building conservation.

Just as in the design of new buildings, the conservation of historic buildings must take into account modern requirements for energy efficiency. Appropriate systems of lighting make a significant contribution to energy efficiency, and the measures described in the following sections, which are introduced largely in the context of modern buildings, are equally important in the renovation of historic and heritage buildings.

\section{ENERGY USE AND ENERGY EFFICIENCY PERFORMANCE IN BUILDINGS}

Energy is one of the key components of the Malaysian economy. The development and utilisation of energy resources, socio-economic welfare of the people and export earnings have contributed towards the industrialization of the economy. The increasing demand for energy from both residential and commercial sectors, has forced the introduction of energy efficiency policies in these sectors. Hence, an assessment of existing energy use and overall energy efficiency performance in buildings is vital.

\section{BUILDINGS AND ENERGY USE}

The Director General of the Ministry of Energy, Telecommunication and Post, Malaysia, stated that energy demand was growing faster than the nation's GDP. The manufacturing and transport sectors increased the final consumption of commercial energy with an average annual growth rate of $6.2 \%$, from 16,119 ktoe in 2009 to 17,180 ktoe in 2012 . The transport sector was the largest energy consumer, utilizing $45 \%(17,180 \mathrm{ktoe})$ of the total final commercial energy demand in 2012, followed by the industrial sector $(36.5 \%, 13,919$ ktoe) and the residential and commercial sectors (18.5\%, 7,064 ktoe) (MEIH, 2011)

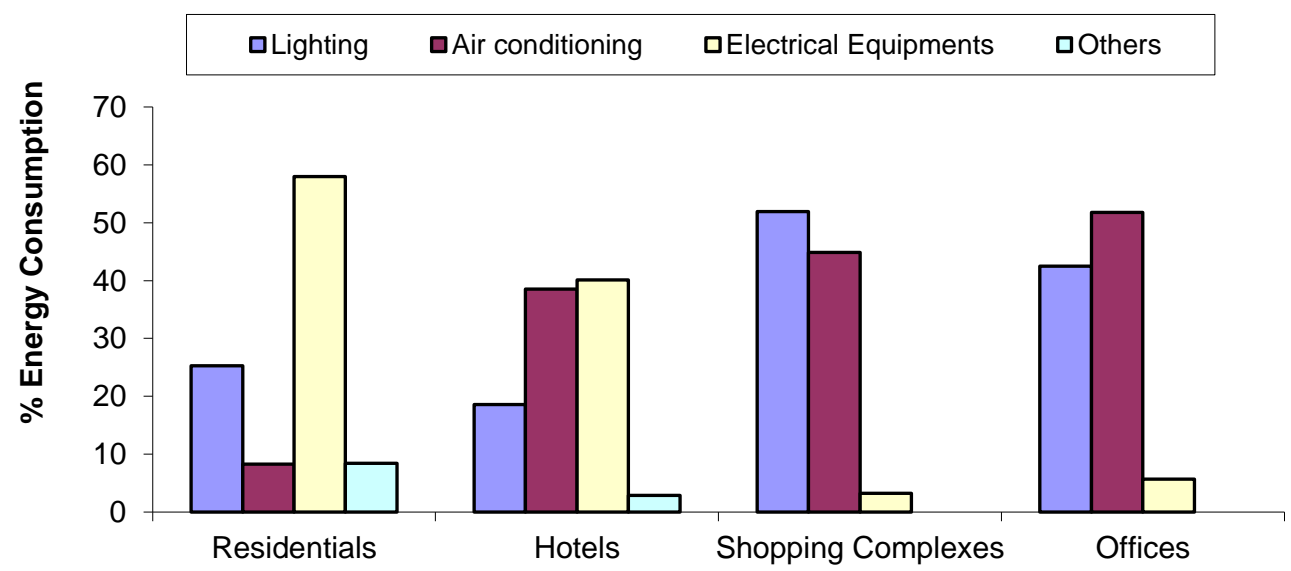

Figure 1.1: Breakdown of energy consumption in the building sector (\%)

(Source: MEIH ,2011)

\section{EVALUATION OF EXISTING BUILDING REGULATIONS IN MALAYSIA}

In 1989, the Ministry of Energy, Communications, and Multimedia Malaysia (MECM), formerly known as the Ministry of Energy, Telecommunications and Posts (METP), produced Malaysian Guidelines for Energy Efficiency in Buildings. It is not mandatory for builders to adopt the measures in the guidelines. These guidelines were based upon the 
Singapore guidelines, which in turn were based on ASHRAE 75 standards (Nicole \& Humphreys, 2002; Taleghani, Tenpierik, Kurvers, \& van den Dobbelsteen, 2013). The guidelines set out minimum standards in the following areas: minimization losses in electrical power and distribution equipment; design of an energy efficient lighting system; design of an efficient air conditioning system; design criteria of the building envelope; and design of a good energy management system.

\section{MALAYSIA UNIFORM BUILDING BY-LAWS (UBBL)}

The Malaysia Uniform Building By-Laws (UBBL) was produced in 1984 and covers the following areas:

i. submission of plans for approval procedures;

ii. space, light and ventilation;

iii. temporary works in the building operation;

iv. structural requirements and fire prevention requirements.

This document is 30 years old and the Department of Electricity and Gas Supply (JBEG), then under the purview of METP, planned to include energy efficiency requirements and renewable energy applications in buildings in UBBL (UBBL, 1984). It is worth observing that a lot of information and research is required regarding all aspects of energy efficiency, and that the use of daylight in buildings to reduce energy consumption for interior lighting is of paramount importance.

MS1525:2007 Code of Practice has been incorporated into UBBL, coming into force in 2007. MS1525:2007 provides the baseline minimum standard for the Green Building Index (GBI) rating tools for energy efficient design. A design falling below the requirements of this code is unlikely to be rated, while designs that are better than the baseline minimum requirements of MS1525:2007 are rewarded (Leong, 2009).

Aun (2009) listed the basic requirements for MS 1525, as follows:

- Architects and engineers are required to comply with MS 1525 requirements for nonresidential buildings with air conditioned areas larger than $4000 \mathrm{sm}$, following the UBBL amendment.

- The ruling applies to new office buildings, commercial complexes, government buildings, hotels with more than 50 rooms, hospitals with more than 50 beds, institutional buildings, high tech factories, colleges and universities, among others.

- Normal shop-offices, non-air conditioned factories and warehouses will not be covered under this standard.

- Engineers will have to ensure compliance with sections 6, 7, 8 and 9 of MS 1525.

\section{GREEN BUILDING INDEX (GBI)}

The Malaysian Institute of Architects (PAM) and the Association of Consulting Engineers Malaysia (ACEM) developed the Green Building Index (GBI). The GBI is an environmental rating system for buildings and is the first comprehensive rating system in Malaysia to evaluate environmental design and performance of buildings. The aim of the GBI is to assist and support the building and construction industry towards sustainable development. It was developed to suit Malaysian tropical weather, environmental, development cultural and social needs (PAM, 2011). 
The objectives of the GBI environmental rating system development are: 1) defining green buildings by establishing a common language and standard of measurement; 2) promoting integrated, whole-building design; 3) recognizing and reward environmental leadership; 4) transforming the built environment to reduce the environmental impact; and 5) ensuring new buildings remain relevant in the future and existing buildings are refurbished and upgraded properly (PAM, 2011).

There are six main criteria in the GBI; namely: Energy Efficiency, Indoor Environment Quality, Sustainable Site Planning \& Management, Materials \& Resources, Water Efficiency, and Innovation. The energy efficiency (EE) is further discussed since this paper is investigating measures for potential energy saving in building lighting performance. The items included in this criterion are minimum EE performance, renewable energy, advanced EE performance based on OTTV \& RTTV, home office and connectivity, and sustainable maintenance. Table 1 presents the area of assessment for the EE criterion.

Table 1: Green Building Index Assessment for Energy Efficiency (EE) Criterion

\begin{tabular}{|c|c|c|}
\hline Item & Criteria & Area of Assessment \\
\hline \multirow[t]{2}{*}{ EE1 } & \multirow[t]{2}{*}{$\begin{array}{l}\text { Minimum EE } \\
\text { performance }\end{array}$} & $\begin{array}{l}\text { Establish minimum EE performance to reduce energy consumption } \\
\text { in buildings, thus reducing } \mathrm{CO}_{2} \text { emission to the atmosphere. }\end{array}$ \\
\hline & & $\begin{array}{l}\text { Apply OTTV and RTTV formulas of MS } 1525 \text { for residential } \\
\text { buildings }\end{array}$ \\
\hline \multirow[t]{3}{*}{ EE2 } & \multirow[t]{3}{*}{ Renewable Energy } & Encourage use of renewable energy \\
\hline & & $\begin{array}{l}\text { a) Low-rise (3-storeys and below, i.e. landed buildings, terrace, } \\
\text { semi-detached \& detached): }\end{array}$ \\
\hline & & $\begin{array}{l}\text { b) Hi-rise (above 3-storeys, building energy consumption here shall } \\
\text { apply to energy consumption in common areas only and not to } \\
\text { the residential units) }\end{array}$ \\
\hline EE3 & $\begin{array}{l}\text { Advanced EE } \\
\text { performance based on } \\
\text { OTTV \& RTTV }\end{array}$ & $\begin{array}{l}\text { Establish EE performance to reduce dependence on energy to keep } \\
\text { indoor environment at satisfactory comfort level. } \\
\text { Computed OTTV and RTTV to show lower dependence on energy to } \\
\text { maintain indoor thermal comfort. }\end{array}$ \\
\hline \multirow[t]{2}{*}{ EE4 } & \multirow[t]{2}{*}{$\begin{array}{l}\text { Home office \& } \\
\text { connectivity }\end{array}$} & $\begin{array}{l}\text { Encourage dual use spaces and working from home, thereby } \\
\text { discouraging avoidable commuting. }\end{array}$ \\
\hline & & $\begin{array}{l}\text { Multiple-use type developments, OR } \\
\text { High speed internet access available in homes }>1 \mathrm{MB} / \mathrm{s}\end{array}$ \\
\hline \multirow[t]{5}{*}{ EE5 } & \multirow[t]{5}{*}{ Sustainable maintenance } & $\begin{array}{l}\text { Ensure that the building's energy-related systems will continue to } \\
\text { perform as intended beyond the } 12 \text { months Defects } \\
\& \text { Liability Period. Document Green Building Design features and } \\
\text { strategies for user information and guidance for sustainable } \\
\text { performance during occupancy }\end{array}$ \\
\hline & & Buildings with Common Management: \\
\hline & & $\begin{array}{l}\text { 1. Provide a designated building maintenance office equipped with } \\
\text { facilities (including tools and instrumentation) and inventory storage; } \\
\text { 2. Provide evidence of documented plan for at least } 3 \text {-year facility } \\
\text { maintenance and preventive maintenance budget; } \\
\text { 3. Provide full set of all Building, Structural and M\&E Plans and } \\
\text { Maintenance manuals to maintenance team; OR }\end{array}$ \\
\hline & & Buildings without Common Management: \\
\hline & & $\begin{array}{l}\text { 1. Provide an evidence of documented plan for at least 3-year } \\
\text { preventive maintenance budget. } \\
\text { 2. Provide full set of all Building, Structural and M\&E Plans and } \\
\text { Maintenance manuals to every building owner }\end{array}$ \\
\hline
\end{tabular}




\section{ENERGY EFFICIENCY REGULATIONS}

Over the years, Malaysia has embarked on many initiatives to respond to the energy efficiency challenges. Rahman Mohamed and Lee (2006) stated that the Malaysian government has implemented an energy efficiency programme for sustainable economic development. The assessment of energy efficiency includes power generation efficiency, electricity transmission and distribution, and various end-uses of energy.

The Malaysian plans, for instance, the Tenth Malaysian Plan, promote energy efficiency among the citizens. The energy efficiency measures are intensified to control potential energy savings, reduction of carbon emissions, and also dependence on fossil fuels. The 2010 National Energy Efficiency Master Plan refers to a holistic implementation roadmap to drive efficiency measures across sectors with a target to achieve cumulative energy savings of 4,000 kilo tonnes (Malaysia, 2010).

There are several initiatives to drive energy efficiency efforts across residential, township, industrial, and other building sectors (Malaysia, 2010). The Energy Efficiency Regulations in Malaysia has still not been enacted; however, the government's efforts to prove that energy efficiency can be achieved cost effectively are ongoing. They aim to gain public confidence by stressing that energy efficiency does not impose a cost penalty and is directly affected by the Energy Efficiency Regulations. In fact, it creates wealth over the medium to long term, through the reduction of energy costs in daily business. The Government of Malaysia is strongly committed to promoting energy efficiency and renewable energy for a cleaner environment for future generations (Moggie, 2001)

\section{SYSTEMATIC LITERATURE REVIEW}

This paper reviews literature on lighting performance in achieving energy saving in buildings; see Table 2 .

Table 2: Review of Literature on Lighting Performance in Buildings

\begin{tabular}{|c|c|c|c|}
\hline Authors & Title & Method used & Findings \& Discussion \\
\hline $\begin{array}{l}\text { Kim and de } \\
\text { Dear (2012) }\end{array}$ & $\begin{array}{l}\text { Nonlinear } \\
\text { relationships between } \\
\text { individual IEQ } \\
\text { factors and overall } \\
\text { workspace } \\
\text { satisfaction }\end{array}$ & $\begin{array}{l}\text { Occupant survey sample } \\
\text { - from University of } \\
\text { California } \\
\text { - Web-based survey } \\
\text { (covers IEQ } \\
\text { dimensions such as } \\
\text { thermal comfort, air } \\
\text { quality, lighting, } \\
\text { acoustic quality, } \\
\text { office layout, office } \\
\text { furnishings and, } \\
\text { cleanliness and } \\
\text { maintenance) }\end{array}$ & $\begin{array}{l}\text { - Thermal discomfort strongly affects } \\
\text { overall satisfaction } \\
\text { i) Overall dissatisfaction decreases } \\
\text { when building performs poorly on } \\
\text { 'temperature', where it is bigger } \\
\text { than the satisfaction increases } \\
\text { when a building performs well on } \\
\text { 'temperature'. } \\
\text { ii) The impact of 'temperature' on } \\
\text { overall satisfaction is higher when } \\
\text { the performance fails to meet } \\
\text { occupants' expectations. } \\
\text { iii) This study proved that the item } \\
\text { 'temperature' has the character of } \\
\text { Kano's Basic Factors } \\
\text { This study proves that Post Occupancy } \\
\text { Evaluation (POE) database indicated } \\
\text { that Kano's model generalizes } \\
\text { successfully to the IEQ domain. } \\
\text { Most of the IEQ factors had a negative } \\
\text { impact (Basic Factors) while the } \\
\text { others had a linear relationship with }\end{array}$ \\
\hline
\end{tabular}




\begin{tabular}{|c|c|c|c|}
\hline & & & $\begin{array}{l}\text { overall satisfaction. } \\
\text { Kano's satisfaction model depends on } \\
\text { expectation levels, which can be } \\
\text { expected to vary through time and } \\
\text { between groups. } \\
\text { Further research - consider how the } \\
\text { categorization of IEQ factors changes } \\
\text { according to the characteristics of } \\
\text { occupancy, including occupant } \\
\text { demographics, ventilation type (e.g. } \\
\text { naturally ventilated, air conditioned, } \\
\text { mixed-mode), office type }\end{array}$ \\
\hline $\begin{array}{l}\text { Musa et al. } \\
\text { (2012) }\end{array}$ & $\begin{array}{l}\text { Indoor } \\
\text { Environmental } \\
\text { Quality for UKM } \\
\text { Architecture Studio: } \\
\text { An } \\
\text { Analysis on Lighting } \\
\text { Performance }\end{array}$ & $\begin{array}{ll}\text { 1. } & \text { Collecting the } \\
\text { lighting data } \\
\text { 2. } & \text { Questionnaire } \\
\text { survey distributed } \\
\text { for UKM year } 3 \\
\text { architecture studio }\end{array}$ & $\begin{array}{l}\text { - Sufficient daylight for tasks performed } \\
\text { within the studio is necessary for good } \\
\text { design of buildings. It can be achieved } \\
\text { by providing ways to allow diffused } \\
\text { light from the sky, but keeping out } \\
\text { direct light from the sun to prevent } \\
\text { heat gain and glare. } \\
\text { High quality lighting improves student } \\
\text { moods, behaviour, concentration, and } \\
\text { therefore their learning. } \\
\text { The artificial light is used most of the } \\
\text { time in UKM architecture studio to } \\
\text { optimize student vision and comfort. } \\
\text { Code of Practice on Energy Efficiency } \\
\text { and use of Renewable Energy for } \\
\text { Non-Residential Building indoor light } \\
\text { requirements. } \\
\text { More effective to provide a low level } \\
\text { of background lighting, sufficient for } \\
\text { orientation and general activities, at } \\
\text { 150 - 200 lux but differently for } \\
\text { studio-based learning. } \\
\text { Lighting has been an important factor } \\
\text { in designing and operating all learning } \\
\text { environments because of its influence } \\
\text { on interacting parameters on the } \\
\text { indoor environment quality (Plymton } \\
\text { et al., 2000; Benya, 2001). } \\
\text { Lighting is one of the most important } \\
\text { parameters in achieving the Indoor } \\
\text { Environment Quality for UKM } \\
\text { architecture studio. The lighting in } \\
\text { year } 3 \text { studio "Needs Improvement" to } \\
\text { achieve better IEQ scenario and to } \\
\text { increase the illuminance level. }\end{array}$ \\
\hline $\begin{array}{l}\text { Aries, Veitch, } \\
\text { and } \\
\text { Newsham } \\
(2010)\end{array}$ & $\begin{array}{l}\text { Windows, view, and } \\
\text { office characteristics } \\
\text { predict physical and } \\
\text { psychological } \\
\text { discomfort }\end{array}$ & $\begin{array}{l}\text { Cross-sectional survey } \\
\text { Respondent - occupants } \\
\text { in office buildings in the } \\
\text { Netherlands }\end{array}$ & $\begin{array}{l}\text { - The lighting quality in an indoor space } \\
\text { affects the work performance, } \\
\text { comfort, and satisfaction of occupants } \\
\text { (e.g., Chung \& Burnett, 2000; Veitch, } \\
\text { 2001b; Veitch \& Newsham, 1998) } \\
\text { Lighting controls affect human } \\
\text { biology, human physiology and } \\
\text { performance } \\
\text { Natural light is better than electric } \\
\text { light - one of the reasons why } \\
\text { windows are so important to building } \\
\text { occupants. }\end{array}$ \\
\hline
\end{tabular}




\begin{tabular}{|c|c|c|c|}
\hline $\begin{array}{l}\text { Ryckaert, } \\
\text { Lootens, } \\
\text { Geldof, and } \\
\text { Hanselaer } \\
(2010)\end{array}$ & $\begin{array}{l}\text { Criteria for energy } \\
\text { efficient lighting in } \\
\text { buildings }\end{array}$ & $\begin{array}{l}\text { The normalized power } \\
\text { density NPD has been } \\
\text { used as the evaluation } \\
\text { criterion - to get a } \\
\text { subsidy for a re- or new } \\
\text { lighting in Flanders. } \\
\text { The lighting installation } \\
\text { relates to the electrical } \\
\text { power - maintained } \\
\text { illuminance on a } \\
\text { reference plane and to } \\
\text { the overall floor area and } \\
\text { is typically expressed in } \\
\mathrm{W} /(\mathrm{m} 2100 \mathrm{x}) \text {. }\end{array}$ & $\begin{array}{l}\text { - Lighting is an important issue in } \\
\text { minimizing overall energy } \\
\text { consumption or industrialized } \\
\text { countries, lighting accounts for } 5-15 \% \\
\text { of the total electric energy } \\
\text { consumption. } \\
\text { The energy consumption of a lighting } \\
\text { installation is strongly dependent on } \\
\text { lighting controls (daylight, presence } \\
\text { detection, dimming, etc.). } \\
\text { Criteria have been tested for several } \\
\text { practical examples: } \\
\text { office room and a storehouse - office } \\
\text { room: an office of } 30 \mathrm{~m} \text { by } 30 \mathrm{~m} \text { with } \\
\text { a height of } 3 \mathrm{~m}\end{array}$ \\
\hline $\begin{array}{l}\text { Nippun } \\
\text { Kumaar, } \\
\text { Kiran, and } \\
\text { Sudarshan } \\
(2010)\end{array}$ & $\begin{array}{l}\text { Intelligent Lighting } \\
\text { System Using } \\
\text { Wireless Sensor } \\
\text { Networks }\end{array}$ & $\begin{array}{l}\text { Hardware: Wireless } \\
\text { Sensor Network, master } \\
\text { node }(M N), \text { sensor node } \\
\text { (SN), and light control } \\
\text { node (LCN). } \\
\text { Software: Frame format, } \\
\text { algorithm, }\end{array}$ & 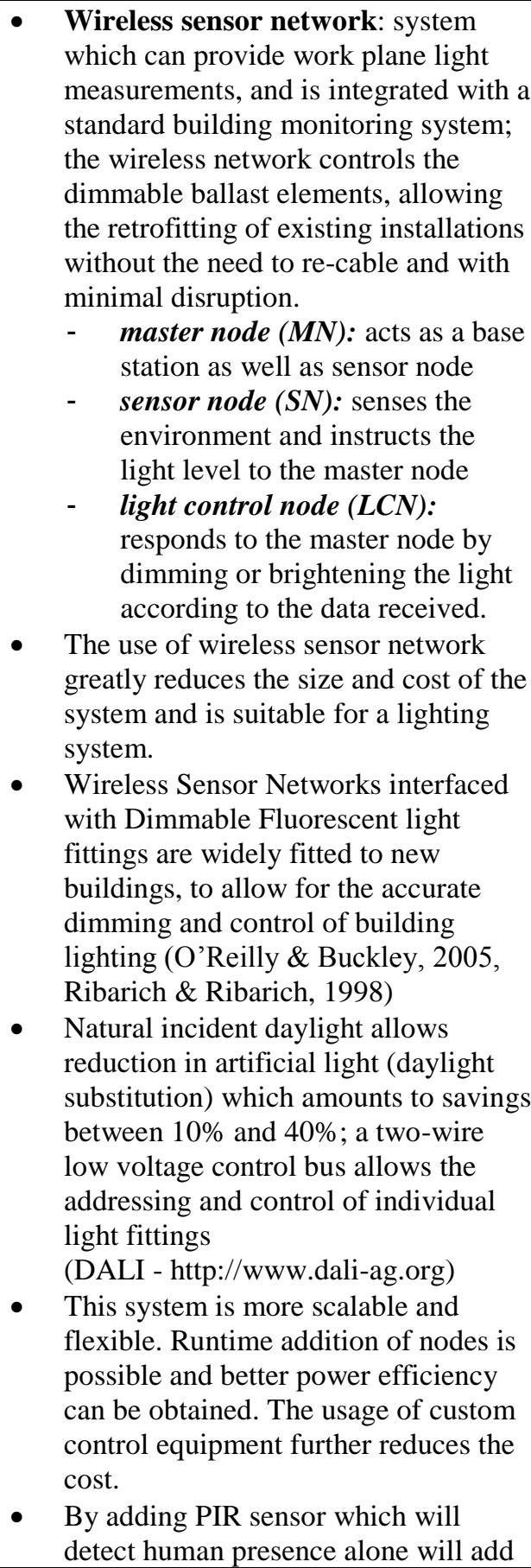 \\
\hline
\end{tabular}




\begin{tabular}{|c|c|c|c|}
\hline & & & $\begin{array}{l}\text { more intelligence to the system and } \\
\text { further helps in reduction of power by } \\
\text { selectively dimming or switching off } \\
\text { some light sources and thus keeping } \\
\text { average power consumption constant }\end{array}$ \\
\hline $\begin{array}{l}\text { Yun, Kim, } \\
\text { and Kim } \\
(2012)\end{array}$ & $\begin{array}{l}\text { Effects of occupancy } \\
\text { and lighting use } \\
\text { patterns on lighting } \\
\text { energy consumption }\end{array}$ & $\begin{array}{l}\text { Survey results from a } \\
\text { monitoring campaign of } \\
\text { four offices in Korea, } \\
\text { which was conducted } \\
\text { from February to June } \\
2010 \\
\text { - } \quad \text { Aim to reveal } \\
\text { occupancy } \\
\text { patterns, occupant } \\
\text { use of lighting } \\
\text { systems, and } \\
\text { resulting lighting } \\
\text { energy use. }\end{array}$ & $\begin{array}{l}\text { - Lighting is one of the largest energy } \\
\text { users in artificially lit buildings. } \\
\text { Daylighting - reduce the needs of } \\
\text { artificial lighting have been } \\
\text { highlighted. However, they have not } \\
\text { always materialized in practice, which } \\
\text { is mainly due to the lack of } \\
\text { understanding of occupant perception } \\
\text { and behaviour of natural and artificial } \\
\text { lighting systems. } \\
\text { Occupant behaviour is a crucial factor } \\
\text { in determining lighting energy use in } \\
\text { buildings (Masoso \& Grobler, 2010) } \\
\text { Light switching patterns during } \\
\text { working hours and showed lighting } \\
\text { are on although daylight is enough to } \\
\text { provide adequate illumination } \\
\text { (Lindelöf \& Morel, 2006) } \\
\text { Occupants tend to turn on lighting } \\
\text { habitually as they first enter an office } \\
\text { and keep the lighting on until they } \\
\text { leave. The results show that there is a } \\
\text { close link between the start of daily } \\
\text { occupancy and the first lighting switch } \\
\text { on event in the investigated office. }\end{array}$ \\
\hline
\end{tabular}

\section{DISCUSSION}

Lighting is an important factor in designing an operating environment to achieve better indoor environment quality (IEQ) and increased luminance level. Better lighting performance has biological, psychological and performance implications, minimizing overall energy consumption and achieving savings and efficiency.

\section{LIGHTING ENERGY PERFORMANCE}

Lighting is a substantial energy consumer and a major component of the services cost. Nevertheless, the use of electricity for lighting is generally inefficient. Consequently, there is potential to improve the energy efficiency of lighting systems throughout the world. The amount of energy consumed by a lighting installation depends on the power consumption of the luminaries and the length of time for which they are switched on (CIBSE, 1998). These practices have considerable potential for energy and cost savings in existing buildings. The energy and cost savings of 30\%-50\% have been achieved (DOE, 1995). Even where lighting is not responsible for the largest energy consumption, reduction in lighting would lead to reducing the cooling load as well as global warming and the greenhouse effect. With an abundance of sunlight, it is an advantage for Malaysia to achieve sufficient illumination for substantial periods in buildings without the need for electric lighting. 
A very energy efficient lighting system will not be a good advertisement for energy saving if people do not like it. On the other hand, an increasing level of environmental awareness in society may result in people disliking energy wasteful systems. A compromise approach needs to be adopted, balancing the needs of energy efficiency and aesthetics.

\section{ENERGY EFFICIENCY MEASURES}

Lighting is an important issue because it directly affects wellbeing, productivity and occupant satisfaction. It is a major consumer of energy and can generate high maintenance and running costs. Lighting energy efficiency measures include occupants' perception of lighting and the control of daylight. Daylight reduces the air conditioning energy requirement because the internal cooling load from the light is reduced. The control of daylight can save energy by dimming down or switching off electric lights. The use of artificial lighting not only refers to the energy consumption but directly disperses waste heat into the building or room space and contributes to the cooling load. However, the effective use of daylight can significantly improve heat reduction, and the cooling and lighting energy required for buildings. Annual operating costs and equipment cost can also be reduced.

\section{Occupants' Perception}

An assessment of the occupants' opinion of a building's internal environment can be obtained through their responses to a questionnaire (Huang, Zhu, Ouyang, \& Cao, 2012; Kim, de Dear, Cândido, Zhang, \& Arens, 2013; Levermore, Lowe, \& Ure, 1999), with increasing awareness of the role of the indoor environment on occupants' productivity and efficiency. Kamaruzzaman, Egbu, Zawawi, Ali, and Che-Ani (2011) believe that the findings from questionnaire surveys are assisting researchers to identify particular aspects of the environment that require adjustment and improvement. They also provide better internal environment for the occupants. Cuttle (1983) conducted a study to investigate the perceived attributes of windows by using personally administered questionnaires in England and New Zealand, while Heerwagen and Orians (1986) surveyed occupant satisfaction in office buildings in Seattle, USA, during winter and summer.

\section{Daylight}

Bodart and De Herde (2002) evaluated lighting energy savings on global energy consumption in office buildings by using an integrated approach combining daylighting and thermal aspects. The results suggested that potential energy savings can be achieved by integrating the availability of daylight in the electric lighting management, reducing the artificial lighting consumption from $50 \%$ to $80 \%$. From field study measurements, Galasiu, Atif, and MacDonald (2004) proved that a lighting energy system can reduce the electricity consumption on average between 50\%-60\% when compared to lights fully on from 6 AM to 6 PM under these conditions which include a clear sky and without blinds. These savings, however, dropped by 5\%-45\% for the dimming system, and 5\%-80\% for the automatic on/off system with the introduction of various static window blind configurations.

It must be clearly understood that energy is not saved by daylight itself but the energy is saved by dimming down or switching off electric lights that are unnecessary because of the existence of daylight. Therefore, daylighting reduces air conditioning energy requirements because the internal cooling load from the lights is reduced. This additional cooling load saving benefits buildings with large cooling loads as long as the daylighting apertures have proper sun control to avoid excessive solar heat gain (Rea \& Maniccia, 1994). 
Many new energy-efficient electric lighting technologies, such as rare-earth fluorescent lamps, high-frequency electronic ballasts, or occupancy sensors, have significantly reduced lighting power requirements. Daylighting can lower electricity demand charges. Modern building energy management control systems can dim lights to shave peak demand or in response to load shortage signals from the electric utility. Peak load reductions realized through daylighting reduce the demand for power when supplies are often met by less environmentally friendly power sources.

Daylight allows people to continue working on some tasks during power outages. This argument for using daylight is becoming less convincing as offices and businesses increasingly rely on electricity for running computers, copiers, and other office equipment. Nonetheless, if daylighting can remove demand from back-up generators, more power will be available during power interruptions for critical business machines.

Moreover, daylight linked to control systems plays an important role in reducing the lighting power by utilizing the level of available daylight in a room (Haq et al., 2014). This is because the lighting can be decreased when there is daylight penetration in the space or room by using the control system, which is a switching or dimming method. Haq et al. (2014) mentioned that the lighting control system can maintain adequate light levels required for the task performed in the room. Several daylight evaluation tools are used in building design, including design guides, manual and computer calculation and visual simulation programs, and scale and full-scale models. These tools can:

1) Determine the illuminance levels from daylight at specified points for specified sky conditions.

2) Predict annual daylight energy savings under alternative control strategies.

3) Analyze light distribution within the space. In some cases, high luminance ratios may be desired for dramatic effects or for establishing architectural hierarchies; in others, more uniform lighting may be the objective.

4) Predict the location and time of direct sun within a space. These sun/shade studies are useful in evaluating shading devices and planning for visual and thermal comfort and for the preservation of art and materials.

5) Aesthetically evaluating the interaction of light and the proposed space. Designers use representation to formulate their strategies and to communicate their design intentions to clients.

\section{Lighting Simulation}

The purpose of a building simulation is to imitate the real physical conditions in a building by creating a mathematical model that ideally represents all energy flow paths in a building as well as their interactions. The advance in simulation techniques and computing facilities has led to the development of advanced building simulation tools.

Hensen and Hand (1993) discussed the gap between sophisticated simulation tools and building design professionals. The performance of the simulation does not depend on sophisticated simulation tools alone but also on the user's understanding of the whole simulation. Hong, Chou, and Bong (2000) discussed the state-of-art on the development and application of computer-aided building energy simulation by addressing some crucial questions in the field. MacDonald, Clarke, and Strachan (1999) discussed the uncertainty in building thermal simulation. The proposed approaches are analyzing the uncertainties, using statistical techniques and error analysis of the fundamental equations methods. Pedrini, 
Westphal, and Lamberts (2002) described a methodology for building energy modelling and calibration in Brazil that included simulation from building design plans and documentation, walk-through and audit and end-use energy measurements.

\section{Automatic Lighting Systems}

Haq et al. (2014) provide the latest review of energy efficiency measures for lighting control in buildings. The automatic lighting control system is one of the measures that can reduce energy consumption by decreasing the operating time of lamps based on various factors like occupancy, time of day and availability of daylight. Factors that affect the performance of the control systems include the usage pattern of occupants and the type of control system. The occupancy sensors, for example, time-delay setting, are a key issue which can have an impact on their performance; while for daylight-linked systems, choosing between switching and dimming is important for successful implementation. Different parameters can be used to control lighting, and misunderstanding or failure to fully understand these parameters can cause the inappropriate lighting that can degrade energy saving performance and cause user dissatisfaction.

Moreover, the lighting control system can provide significant energy savings and therefore reduce the electricity costs. The reduction of the electricity demand has a positive environmental impact that can decrease the carbon footprint. Various properties of the control technologies can affect the performance. For example, the installed lighting power can be reduced by using more efficient lamps which produce an adequate amount of lighting output using as little power input as possible. The lighting load can also be reduced by proper lighting design, such as task lighting which provides appropriate levels of light where the tasks are performed (Haq et al., 2014).

\section{CONCLUSION}

Lighting is a form of energy that stimulates our sense of vision. Appropriate lighting can improve job performance, while poorly designed lighting can cause wastage and health problems. Lighting includes the use of artificial light sources such as lamps, and natural illumination of interiors from daylight. Lighting levels affect behaviour, including productivity and absenteeism of staff; the lighting level can decrease productivity while increasing absenteeism due to illness occurring in the workplace.

As we know, majority of people spend times inside buildings, especially in modern society. With urbanization, buildings have evolved from simple shelters for the occupants to advanced, self-contained and tightly controlled environments that provide various services to their occupants. These services include environmental conditioning, vertical transportation, sanitation, artificial lighting, communications and security, and the buildings need to consume energy in order to perform these functions. Most buildings have high energy needs to function and be useful for the occupants.

However, energy can be wasted due to poor quality of older buildings, and this wastage can affect the environment and the economy. Thus, the environmental impact of the building can be overcome by reducing the energy wastage, and it is clear that appropriate lighting can reduce energy consumption in daily life. Moreover, the inefficient use of energy in buildings can affect the economy of the whole country. The use of energy can be reduced by improving the building fabric, plant and environmental control. As a result, these can provide 
comfortable conditions that can directly affect occupant satisfaction and productivity in their work.

In conclusion, strategies to measure effective energy savings in Malaysian historic buildings are essential for efficient lighting. This study establishes a systematic approach to the refurbishment of lighting in Malaysian buildings to increase energy efficiency. It may provide useful information for achieving optimum energy efficiency, savings in monetary terms as well as reducing the environmental impact.

\section{ACKNOWLEDGEMENTS}

The authors gratefully acknowledge the financial support of the University of Malaya High Impact Research (HIR), grant no UM.C/625/1/HIR/ASH/013 established at the University of Malaya, Malaysia.

\section{REFERENCES}

Aries, M. B. C., Veitch, J. A., \& Newsham, G. R. (2010). Windows, view, and office characteristics predict physical and psychological discomfort. Journal of Environmental Psychology, 30(4), 533-541. doi: 10.1016/j.jenvp.2009.12.004

Aun, C.S. (2009, February 14). GREEN BUILDING INDEX - MS1525: Applying MS1525:2007 Code of Practice on Energy Efficiency and Use of Renewable Energy for Non-Residential Buildings. Paper presented at GBI CPD Seminar, Penang. Malaysia: Pertubuhan Arkitek Malaysia

Bassi, A. M., Yudken, J. S., \& Ruth, M. (2009). Climate policy impacts on the competitiveness of energy-intensive manufacturing sectors. Energy Policy, 37(8), 3052-3060. doi: http://dx.doi.org/10.1016/j.enpol.2009.03.055

Bernard, M. (2003). Conservation of Historical Building: Introduction to Architectural Conservation. Great Britain: St. Edmundsbury Press Ltd.

Bodart, M., \& De Herde, A. (2002). Global Energy Savings in Offices Buildings by the Use of Daylighting. Energy and Buildings, 34, 421-429.

Boyano, A., Hernandez, P., \& Wolf, O. (2013). Energy demands and potential savings in European office buildings: Case studies based on EnergyPlus simulations. Energy and Buildings, 65(0), 19-28. doi: http://dx.doi.org/10.1016/j.enbuild.2013.05.039

CIBSE. (1998). Building Energy and Environmental Modeling, Applications Manual AM11. London: The Chartered Institution of Building Services Engineers.

Cuttle, C. (1983). People and Windows in Workplaces. . Paper presented at the Proceedings of the People and Physical Environment Research Conference Wellington, New Zealand.

DOE. (1995). Energy Efficient Refurbishment of Public Houses-Lighting, Good Practice: Guide 152. United Kingdom: Department of Environment.

Galasiu, A. D., Atif, M. R., \& MacDonald, R. A. (2004). Impact of window blinds on daylight-linked dimming and automatic on/off lighting controls. Solar Energy, 76, 523-544.

Haq, M. A. U., Hassan, M. Y., Abdullah, H., Rahman, H. A., Abdullah, M. P., Hussin, F., \& Said, D. M. (2014). A review on lighting control technologies in commercial buildings, their performance and affecting factors. Renewable and Sustainable Energy Reviews, 33(0), 268-279. doi: http://dx.doi.org/10.1016/j.rser.2014.01.090

Harun, S. N. (2011). Heritage building conservation in Malaysia: Experience and challenges. Proceedia Engineering, 20, 41-50. 
Heerwagen, J., \& Orians, G. (1986). Adaptations to windowlessness: A study of the use of visual décor in windowed and windowless offices. Environment and Behavior, 18, 623-639.

Hensen, J. L. M., \& Hand, J. W. (1993). Use of Sophisticated Building Energy Simulation Tools. Paper presented at the 3rd European Conference on Architecture "Solar energy in architecture and urban planning", Florence.

Hong, T., Chou, S. K., \& Bong, T. Y. (2000). Building simulation: An overview of developments and information sources. Building and Environment, 35, 347-361.

Huang, L., Zhu, Y., Ouyang, Q., \& Cao, B. (2012). A study on the effects of thermal, luminous, and acoustic environments on indoor environmental comfort in offices. Building and Environment, 49(0), 304-309. doi: http://dx.doi.org/10.1016/j.buildenv.2011.07.022

Kamal, K. S., Wahab, L. A., \& Ahmad, A. G. (2008). Pilot Survey on the Conservation of Historical Buildings in Malaysia. Paper presented at the 2nd. International Conference on Built Environment in Developing Countries 2008 "Sustainable Built Environment: Bridging Theory and Practice" University Science Malaysia.

Kamaruzzaman, S., \& Edwards, R. (2006). Evaluating Peformance Characteristics of Electricity Use of British Historic Buildings in Malaysia. Facilities, 24 (3/4), 141152.

Kamaruzzaman, S. N., Egbu, C. O., Zawawi, E. M. A., Ali, A. S., \& Che-Ani, A. I. (2011). The effect of indoor environmental quality on occupants' perception of performance: A case study of refurbished historic buildings in Malaysia. Energy and Buildings, 43(2-3), 407-413. doi: http://dx.doi.org/10.1016/j.enbuild.2010.10.003

Kim, J., \& de Dear, R. (2012). Nonlinear relationships between individual IEQ factors and overall workspace satisfaction. Building and Environment, 49, 33-40. doi: 10.1016/j.buildenv.2011. 09.022

Kim, J., de Dear, R., Cândido, C., Zhang, H., \& Arens, E. (2013). Gender differences in office occupant perception of indoor environmental quality (IEQ). Building and Environment, 70(0), 245-256. doi: http://dx.doi.org/10.1016/j.buildenv.2013.08.022

Leong, V.K. (2009, July 25). MS1525:2007 Clause 5: Building envelope. Paper presented at GBI CPD Seminar, Penang. Malaysia: Green Building Index Sdn Bhd.

Levermore, G. J., Lowe, D., \& Ure, J. (1999). Occupant Feedback Questionnaire Producing a Fingerprint and a Score, ASHRAE.

MacDonald, A. I., Clarke, J. A., \& Strachan, P. A. (1999). Building simulation: An overview of developments and information sources. Paper presented at the Building Simulation 99.

Malaysia. (2010). Tenth Malaysia Plan 2011-2015. Prime Minister's Department, Putrajaya

MEIH. (2011). Statistics: Malaysia Energy Information Hub. Retrieved 2 January 2013, from http://meih.st.gov.my/statistics;jsessionid=F68BE3730C50F0709BD8B651F0070B6C

Moggie, A. L. (2001). [Press release]. Retrieved from http://www.kettha.gov.my/content/national-seminar-low-energy-office-leo-building

Musa, A. R., Abdullah, N. A. G., Che-Ani, A. I., Tawil, N. M., \& Tahir, M. M. (2012). Indoor environmental quality for UKM architecture studio: An analysis on lighting performance. Procedia - Social and Behavioral Sciences, 60(0), 318-324. doi: http://dx.doi.org/10. 1016/j.sbspro.2012.09.386

Mustapa, S. A., Kamal, K. S., \& Zainul, M. Z. (2005). Rehabilitation of heritage buildings in Malaysia. Paper presented at the International Seminar on Modern Urban and Architectural Heritage, Jakarta. 
Nicole, J. F., \& Humphreys, M. A. (2002). Adaptive thermal comfort and sustainable thermal standards for buildings. Energy and Buildings, 34, 563-572

Nippun Kumaar, A. A., Kiran, G., \& Sudarshan, T. S. B. (2010). Intelligent lighting system using wireless sensor networks. International Journal of Ad hoc, Sensor \& Ubiquitous Computing, 1(4), 17-27. doi: 10.5121/ijasuc.2010.1402

Ozolina, L., \& Roša, M. (2012). A review of energy efficiency policy and measures for industries in Latvia. Management of Environmental Quality: An International Journal, 23(5), 517-526. doi: 10.1108/14777831211255097

Pedrini, A., Westphal, F. S., \& Lamberts, R. (2002). A methodology for building energy modelling and calibration in warm climate. Building and Environment, 37, 903-912.

PAM, Pertubuhan Arkitek Malaysia, (2011). Green Building Index (GBI) Rating System. Malaysia: Kuala Lumpur.

Rahman Mohamed, A., \& Lee, K. T. (2006). Energy for sustainable development in Malaysia: Energy policy and alternative energy. Energy Policy, 34(15), 2388-2397. doi: http://dx.doi. org/10.1016/j.enpol.2005.04.003

Rea, M. S., \& Maniccia, D. (1994). Lighting controls a scoping study. New York: Rensselaer Polytechnic Institute Lighting Research Center.

Ryckaert, W. R., Lootens, C., Geldof, J., \& Hanselaer, P. (2010). Criteria for energy efficient lighting in buildings. Energy and Buildings, 42(3), 341-347. doi: http://dx.doi.org /10.1016/j.enbuild.2009.09.012

Salleh, N. H., \& Ahmad, A. G. (2009). Fire safety management in heritage buildings: The current scenario in Malaysia. Paper presented at the 22nd CIPA Symposium, Kyoto, Japan

Taleghani, M., Tenpierik, M., Kurvers, S., \& van den Dobbelsteen, A. (2013). A review into thermal comfort in buildings. Renewable and Sustainable Energy Reviews, 26(0), 201-215. doi: http://dx.doi.org/10.1016/j.rser.2013.05.050

UBBL (1984). Uniform Building by Law: Arrangement of by-Laws.

Yaacob, N. (2010). A study of refurbishment of listed buildings into a new facility. Universiti Malaysia Pahang.

Yun, G. Y., Kim, H., \& Kim, J. T. (2012). Effects of occupancy and lighting use patterns on lighting energy consumption. Energy and Buildings, 46, 152-158. doi: 10.1016/j.enbuild.2011.10.034 